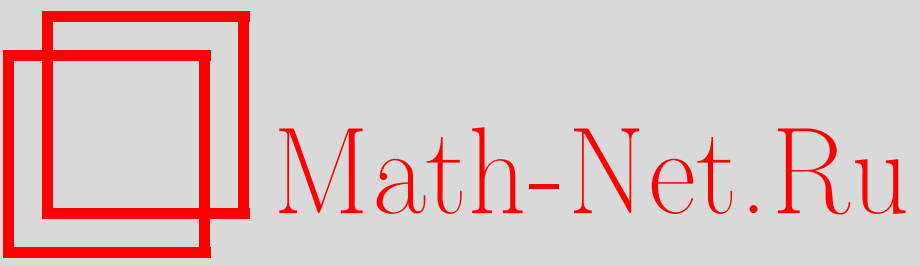

Информация о работе большого семинара кафедры теории вероятностей механико-математического факультета МГУ, Теория вероятн. и ее примен., 2009, том 54, выпуск 2, 410-411

DOI: https://doi.org/10.4213/tvp2801

Использование Общероссийского математического портала Math-Net.Ru подразумевает, что вы прочитали и согласны с пользовательским соглашением

http://www. mathnet.ru/rus/agreement

Параметры загрузки:

IP : 35.174 .16 .151

26 апреля 2023 г., 14:41:57 


\section{ИНФОРМАЦИЯ О РАБОТЕ БОЛЬШОГО СЕМИНАРА КАФЕДРЫ ТЕОРИИ ВЕРОЯТНОСТЕЙ МЕХАНИКО-МАТЕМАТИЧЕСКОГО ФАКУЛЬТЕТА МГУ}

Семинар является продолжением научно-исследовательского семинара кафедры теории вероятностей под руководством А. Н. Колмогорова и Б. В. Гнеденко.

В настоящее время руководителем семинара является чл.-корр. РАН профессор А. Н. Ширяев.

Заседания семинара проходят по средам с 16 ч. 45 мин. в аудитории 16-24 главного здания МГУ. С текущей информацией о работе семинара можно ознакомиться на кафедре теории вероятностей (тел.: (495) 939-14-03, адрес в интернете: http://mech.math.msu.su/probab).

С мая 2000 г. предзащиты кандидатских диссертаций студентов кафедры теории вероятностей проходят на Большом семинаре.

Информация о будущих докладах рассылается по электронной почте. Заявку на ее регулярное получение можно сделать ученому секретарю семинара.

Ниже приводится полный список докладов, представленных на заседаниях семинара в весеннем семестре 2009 г.

11 февраля - В.И. Питербарг (Москва). Физические экстремумы гауссовских прочессов.

18 февраля - А. Н. Ширяев (Москва). О стохастическом правиле «Виу апd Hold» в финансовой математике.

25 февраля - А. Г. Дьячков (Москва). ДНК-коды для аддитивного стебельного сходства.

4 марта - Г. Пфлюг (Вена). Многоэтапное принятие решений в финансах: устойчивость во времени или монотонность по информачии.

11 марта - Н. Ю. Крыжановская (Москва). Предзащита кандидатской диссертации: Статистический предельные теоремы для слабо зависимых случайных полей. Научный руководитель: профессор А. В. Булинский

18 марта - М. А. Лифшиц (Лилль). Аппроксимачия случайных полей тензорного тuпа.

25 марта - А. Г. Тартаковский (Лос-Анжелес). Эффективные численнье методы для оптимизачии и оченки характеристик прочедур обнаружения разладки.

8 апреля - В.В. Щербаков (Москва). О статистических и вероятностных задачах, связанньх с физическими моделями адсорбции.

15 апреля - М. В. Житлухин (Москва). О вероятности выхода броуновского движения и броуновского моста на прямолинейные границы.

Я. А. Люлько (Москва). Стохастические представления функиионалов «максимального» типа от случайного блуждания.

А. А. Муравлёв (Москва). О моментах остановки, связанных с падением $и$ ростом броуновского движения со сносом.

29 апреля - Д. Б. Рохлин (Ростов-на-Дону). Избраннье задачи математической теории арбитража.

13 мая - В. В. Сенатов (Москва). Центральная предельная теорема. Точность аппроксимачии и асимптотические разложения. Рассказ о книге. 
20 мая - В. Р. Фаталов (Москва). Точные асимптотики вероятностных распределений и функииональных интегралов: метод Лапласа.

Координатор семинара в весеннем семестре 2009 г. профессор В. И. Питербарг, Ученый секретарь семинара в весеннем семестре 2009 г.

\section{ИНФОРМАЦИЯ О ВОСЬМОЙ КОЛМОГОРОВСКОЙ СТУДЕНЧЕСКОЙ ОЛИМПИАДЕ ПО ТЕОРИИ ВЕРОЯТНОСТЕЙ}

В ознаменование дня рождения А.Н. Колмогорова кафедра теории вероятностей механико-математического факультета Московского государственного университета им. М.В.Ломоносова при поддержке Московской государственной академии тонкой химической технологии им. М.В.Ломоносова провела восьмую Колмогоровскую студенческую олимпиаду по теории вероятностей. Информация о предыдущих олимпиадах содержится на сайте кафедры теории вероятностей (http://mech.math.msu.su/probab), см. также предыдущие выпуски журнала.

Олимпиада была проведена 18 апреля 2009 г. раздельно для I-II и III-V курсов (продолжительность - 5 часов). Оргкомитет констатирует, что в олимпиаде приняли участие 38 студентов I-II курсов и 41 студент III-V курсов механикоматематического факультета, факультета ВМиК, химического факультета и факультета наук о материалах Московского государственного университета, а также Государственного университета «Высшая школа экономики», механико-математического факультета Киевского национального университета, математико-механического факультета Санкт-Петербургского государственного университета, факультета прикладной математики и компьютерных технологий Вологодского государственного педагогического университета.

\section{Предлагавшиеся на олимпиаде задачи}

В скобках после номера задачи указываются курсы, на которых предлагалась данная задача, затем число решивших ее студентов I-II курсов и, наконец, число студентов III-V курсов, решивших эту задачу.

Задача 1. (I-II; 15) Пусть случайная величина $X$ имеет конечную дисперсию и не равна тождественно нулю. Доказать, что $\mathbf{P}(X=0) \leq\left(\mathbf{E} X^{2}\right)^{-1} \mathbf{D} X$.

Задача 2. (I-V; 8, 4) Пусть множества $A_{1}, \ldots, A_{2000} \subset A$ содержат по крайней мере по 6 элементов каждое и не все эти множества совпадают. Доказать, что существует 100 таких различных разбиений множества $A$ на 5 попарно непересекающихся подмножеств $E_{1}, \ldots, E_{5}$, что каждое множество $A_{i}$ содержит представителей хотя бы двух подмножеств $E_{i}$.

Задача 3. (I-V; 19, 29) Из контейнера $A$, в котором было 1000 зеленых и 3000 красных яблок, взяли половину яблок и перенесли в контейнер $B$, в котором к тому времени уже лежало 3000 зеленых и 1000 красных яблок. Затем из контейнера $B$ извлекли одно яблоко. Найти вероятность, что оно зеленое.

Задача 4. (I-V; 2, 5) Жители города Н. любят после работы, которая у каждого заканчивается в случайный момент, уделить некоторое время рыбалке. В озере водятся караси и лещи, причем доля лещей равна $p$. В городе действует закон, запрещающий ловить более одного леща за день, а горожане исключительно законопослушны и после первой поимки леща сразу возвращаются домой. Найти долю лещей среди всей пойманной в городе рыбы. 